\title{
Challenges and opportunities faced by informal peace committees in Peace Building in Nairobi County
}

\author{
Gacaga Peter Mungai, Prof Crispinous Iteyo and Dr. Janet Kassilly
}

Department of peace and conflict studies Masinde Muliro University of science and Technology

DOI: 10.29322/IJSRP.10.10.2020.p10662

http://dx.doi.org/10.29322/IJSRP.10.10.2020.p10662

\section{Abstract- Background}

In recent years, informal peace committees have rapidly made their mark either as precautionary or as response mechanisms to particular conflicts. The main purpose of this study was to examine the efficacy of informal peace committees in peace building in Nairobi County, Kenya since 1990

Objective

To assess the challenges and opportunities faced by informal peace committees in peace building in Nairobi County

\section{Method}

To accomplish this, the study population consisted of 1260 and a sample size of 509 respondents involved in peace building provided feedback on the effectiveness of informal peace committees. The study collected primary data from interviews, focus group discussions and questionnaires, while secondary data was collected from various databases. The study generated both quantitative and qualitative data. Descriptive statistics data analysis method was applied to analyze numerical data gathered using closed ended questions. Quantitative data was analyzed using descriptive statistics by use of SPSS programme

\section{Results}

The study findings revealed that despite several challenges faced by informal peace committees, they have demonstrated their ability to prevent the eruption or escalation of nascent micro-level conflict into violent and more widespread conflicts

Conclusion

The study concluded that informal peace committees are often small and simple initiatives, yet effective and sustainable. They are small in that they do not involve official bureaucratic structures, but are local structures that are developed from within the community. Such initiatives are usually guided by culture specific cultural norms and values and that is what makes them more local but legitimate in their host communities. The strengths of community-led initiatives are that they address the community's basic needs and challenges and can be replicated.

\section{INTRODUCTION}

$\mathrm{T}$ he study is part of a larger research project, which was designed using Descriptive statistics data analysis method was applied to analyze numerical data gathered using closed ended questions. Quantitative data was analyzed using descriptive statistics by use of SPSS programme. The central objective of this study was to examine the extent to which informal peace committees can effectively contribute to peace building in Nairobi County. The paper is structured as follows: the Background and study locale section describes the context and study location. The Peace building theory' section reviews peace building theory. The Literature review section reviews literature on peace building and the comparative advantages of peace committees over other formations. The Research process describes the data collection procedures. The Results and discussion presents and analyses data. The Concluding remarks sums up the entire study.

\section{BACKGROUND AND STUDY LOCALE}

Building lasting peace in the aftermath of a conflict is one of the biggest development challenges of our time. By most accounts, more than 50 per cent of countries emerging from civil war revert to violent conflict after a brief period of peace (Barbara Walter, 2014). This means that countries mired in war tend to find themselves in a situation known as the conflict trap. That is, societies that have experienced one civil war are more likely to experience a second or third war than are societies with no prior history of war (Hegre et al., 2011). Yet, despite the virus of postconflict relapse, a systematic analysis of the literature and empirical evidence show that there is a remarkable variation in the fates of states following civil war. While some became trapped in an intractable cycle of war and lawlessness, others have managed to sustain peace and even experience democratic consolidation after the end of conflicts.

Kenya has since the adoption of multi party politics in the early 1990s tried various peace building initiatives aimed at fostering cohesion and integration which can help reduce and prevent violence and ultimately reconcile the Kenyan people without success. The country has experienced violence especially during election cycles exposing deep rooted issues which have not been addressed in the past. The country remained polarized due to a combination of historical grievances including; unequal distribution of national resources, entrenched politics of exclusion and patronage, weak national institutions among other issues. This problem has been attributed to a cleavage between peace building processes at the local and national levels. The actors at the local level are only considered useful as victims of conflict and/or recipients of humanitarian aid, making the process of peace an activity that concerns state actors and political elites.

Nairobi has experienced all sorts of violence and conflicts associated to all manner of reasons (Mbugua, 2013). This includes social fragmentation, politicized ethnicity, and partisan politics, where political entrepreneurs use ethnic affiliation to manipulate ethnic grievances. This has been the basis for political mobilization to gain power and control over resources. Corruption 
and impunity which has severely compromised the security sector, while impunity and lack of justice legitimize violence and lead to revenge attacks. Land and development projects, inequity in land ownership and access cause widespread grievances, as do development projects that are not delivered in a conflict-sensitive manner. Discrimination and marginalization of certain groups and areas have faced long-term discrimination and marginalization, which has been exploited by violent extremists. This has provided more opportunities for violence and wider insecurity and in the long run hampers the process of peace building.

There are various peace building intervention mechanisms that have been touted as the best including bottom-up approach or top-down approach (Gastrwo, 1995). Informal peace committees are intervention mechanisms at village, town or regional level which are often considered transitional mechanisms that use bottom-up approach in their peace building. These practices and policies, as internationalized as they may be, do not work. What explains this variation? In other words, how and why do some conflicts end in a peace that endures while other conflicts reignite? Although academicians and development practitioners have vigorously debated this question relying on statistical as well as qualitative methods, there is still quite limited knowledge about how to re-establish sustainable peace after a conflict. It is against this background that the study was undertaken to fill the missing knowledge gap by examining the efficacy of informal peace committee's in peace building in Nairobi County, Kenya, since 1990.

The city stands at Latitude and Longitude of-1.2833, 36.8167 respectively and GPS coordinates of $1^{\circ} 16^{\prime} 59.9880^{\prime \prime} \mathrm{S}$ and $36^{\circ} 49^{\prime} 0.0120^{\prime \prime} \mathrm{E}$. The study specifically focused on the period since 1990. Kenya's capital city, Nairobi, is the most dynamic city, also known as the "green city in the sun" for many reasons. It is Kenya's largest city with a population of nearly four million. It's a city that blends people from all cultures and walks of life. As the largest center of business and trade in East Africa, Nairobi is also the regional location of and headquarters for various international companies and organizations. The central business district also houses many of Kenya's big businesses and banks, including the Nairobi Stock Exchange. Being the center of government and its organizations, Nairobi is the city where most business is transacted in Kenya

\section{PEACE BUILDING THEORY}

(Michael Barnett et al. 2007), argued that peace, is creating the conditions under which individuals in society can benefit from coherent legal frameworks, public order, political stability, and economic opportunities. Building lasting peace in the aftermath of a conflict is one of the biggest development challenges of our time. By most accounts, more than 50 per cent of countries emerging from civil war revert to violent conflict after a brief period of peace (Barbara Walter, 2014). Conflict Transformation Theory by Johan Galtung (2007) was meant to order to design and reframe the way in which peace building initiatives are discussed and pursued, particularly in contexts of ethnic conflict. Traditionally the emphasis has been on conflict resolution and conflict management methods, which focused on reducing or defusing outbreaks of hostility. Conflict transformation, in contrast, places a greater weight on addressing the underlying conditions which give rise to that conflict; preferably well in advance of any hostility, but also to ensure a sustainable peace. In other terms, it attempts to make explicit and then reshape the social structures and dynamics behind the conflict, often employing analytical tools borrowed from systems thinking.

(Galtung, (2013), noted that the cultural violence assembles direct and structural violence with legitimized and internalized violence. He focused on facilitation, mediation, and negotiation to attain cultural peace. The freedom from structural violence definitely assists to restore and maintain peace. It promotes positive peace to move a society toward a fair justice transforming the conflict by peaceful means. Freedom from structural violence enhances dialogue and discourse for peace to oust physical to emotional violence. Freedom from structural violence preserves peace and tranquility advocating freedom from exploitation, repression and separation. The choice of conflict transformation theory in this study was informed by several reasons: For conflict transformation to occur, tensions between parties to the conflict must be overcome - first, by ensuring all actors recognize that their respective interests are not served by resorting to violence; and second, by seeking consensus on what should be transformed and how. Conflict transformation stresses the human dimension by reminding parties of the compatible nature of their needs, instead of emphasizing their opposing interests, and by rejecting unilateral decisions and action, particularly those representing a victory for one of the parties to the conflict;

Conflict transformation does not resort to a predetermined set of approaches and actions, but respects and adapts to the particularities of a given setting; Conflict transformation looks beyond visible issues and is characterized by creative problemsolving, incorporating the perspectives a broad array of actors, including those typically marginalized from such considerations; Conflict transformation invariably involves a third, impartial party, in order to help actors alter their cognitive and emotional views on the 'Other', thereby helping to break down divisions between 'Us' and 'Them'; Conflict transformation represents an ambitious and demanding task, which is better equipped to contend with the asymmetric, complex and protracted nature of contemporary conflicts than prevailing techniques and approaches. Conflict Transformation Theory presented a systematic analysis of different schools of thought that explained why different actors choose different ways to build peace, and where they derived their underlying theories from (explicitly or implicitly). The theory also presented new and critical research thinking in peace building that might impact on practitioners work in the future. Gatling's Conflict Transformation Theory was very useful in helping the study to understand peace building. Again, the study was able to gather some very important milestone in conflict transformation meant to design and reframe the way in which peace building initiatives are discussed and pursued, particularly in contexts of political, ethnic, religious, resourcerelated, and gender-based violence, namely:

The aim of Conflict Transformation is to channel the energy generated by conflict in constructive and non-violent ways rather than destructive and violent directions. Thus, conflict transformation doesn't eliminate conflict but utilizes conflictual processes for generative and positive change. In this way, conflict transformation works to develop resilient personal and social

This publication is licensed under Creative Commons Attribution CC BY

http://dx.doi.org/10.29322/IJSRP.10.10.2020.p10662

WWW.ijsrp.org 
systems where security is enhanced by the quality of community relationships. Conflict transformation occurs when violence ceases and/or is expressed in nonviolent ways, and when the original structural sources of the conflict (economic, social, political, military, and cultural) are changed in some ways. The propensity for violence is diminished by democratization, demilitarization, de-alignment, socio-economic development, and expansion of human rights, humanitarian law, and socio-cultural openness. Conflict can be transformed by normal socio-political processes by the parties acting alone, by expert third-party interventions and parties acting together, or by judicious advocacy and political intervention. There needs to be multi-track involvement if good conflict transformation is sought. This means that conflict transformation can take place at any stage of the escalatory cycle. If the conflict turns violent, its transformation may depend on some kind of crisis management or intervention. Later, it may require conciliation, mediation, negotiation, arbitration, and collaborative problem-solving processes. In the end, any lasting conflict transformation involves processes of resolution, reconstruction, and reconciliation.

Although Conflict Transformation Theory was adopted in the study, one of its major weaknesses was that it has limited attention it gives to the autonomous processes of change that transpire within the political system of the conflict-affected society and it was not conclusive enough to address on what type of action or intervention mechanism is appropriate, by whom, and at what time, when conflict escalates. This means it didn't offer a contingency model on what needs to be done to stop the conflict. This therefore necessitated the need for another theory that would be able to address this shortcoming of not only offering the intervention mechanism but also offer the healing of wounds suffered by victims, offenders and the communities. This would help them to collectively resolve their differences and help them deal with the aftermath of the criminal act with an emphasis on repairing the harm from that act, hence the need for Restorative Justice Theory

\section{LITERATURE REVIEW}

(Bar Tal, 2007.), observed that in peace building process, past rivals come to mutual recognition and acceptance, have invested interests and goals in developing peaceful relations, feel mutual trust, positive attitudes as well as sensitivity and consideration of the other party's needs and interests. This transformation of beliefs, attitudes and emotions regarding one's own group, the others and the relationship between them may take decades. $\mathrm{He}$ argued that reconciliation is not needed in all societies but only in those that have been subjected to protracted, intractable conflict; that is, conflicts in which the societies involved evolve a widely shared psychological repertoire that supports the adherence to the conflictive goals, maintain the conflict, delegitimize the opponent and thus negate the possibility of a peaceful resolution of the conflict and prevent the development of peaceful relations. (Gastrow, 1995), argued that reconciliation implied building or rebuilding relationships today that are not haunted by the conflicts and hatreds of yesterday. To ascertain whether a process of reconciliation is under way in a post-conflict society, suggested that three areas can be observed: how the past is integrated and spoken about between former enemies; if relationships are based on the present or past; and if contradictory versions of the past have been reconciled not into one truth of the past but to versions not based on lies and denial from a leading scholar and practitioner of conflict resolution,

(Jacqueline et al. 2007), noted that in Kenya, as elsewhere, IDPs had been killed or maimed when they attempted to return to former homes in areas without adequate peace and order. Persistent insecurity linked to mobilized youth, local impunity, and the failure of the police and legal system makes resettlement and reintegration of the displaced dangerous. Some argue further that the return of the displaced to their former homes challenges gains in land that play into peace agreements. This can trigger further violence from those who currently live on the newly appropriated or vacated land unless there is careful mediation of these property disputes and reconciliation processes.

(Klopp, 2007), argued that without the healing and reconstitution of local social fabrics linked to successful return and reintegration, a country often moves toward more polarization and ethnic separation. Trauma and anger among IDPs, reinforced by the large concentration of victims with sad and horrific stories to tell means that new settlements of the displaced can easily become recruiting grounds for the next round of violence. The displacements shatter cultural cohesion and undermine traditional practices used to mediate disputes, which often depend on the aggrieved meeting face-to-face where the wrongdoing occurred. When violations of the law are left unaddressed locally as victims flee, impunity at the local level becomes entrenched. (Klopp, 2007), further stated that the process of separation produced by displacement created economic challenges. Violence often disrupts the local economy, which depends on interethnic cooperation for market access, labor, and transportation services. The loss of producer's small businesses and farmers often worsens the prospects for local economic recovery where violence occurs. Where IDPs settle, either as integrated displaced or as impoverished settlers on marginal and unproductive lands and urban slums, they generate new challenges. New ethnically homogenous and unsustainable settlements can increase the potential for violent conflicts between the displaced and host communities, even if the two groups share cultural identities, as the newcomers' needs for water, firewood, and other resources create environmental and social damages that spill over to the host community. Relief food in such new settlements can also undercut local economies.

(Kamoet, 2007), observed that IDPs needed to be integrated and recognized in economic empowerment and property restitution. They deserved to be compensated perhaps the most effective measures for remedying economic insecurity that results from an individual's displacement and loss of livelihood. He noted that internal displacement created serious challenges for Peace building, and the two are intertwined. Preventing further displacement and durable solutions to current displacement requires a peace that involves reconstruction and reform of the state and economy at both local and national levels. This includes not only resettlement but dispute resolution; adjudication of property, especially land disputes; and attack on impunity through reinforcing law and order, in not only the police force but also the courts and mediation systems. According to (Simiyu, 2008), all too often, displacement and its aftermath are viewed within a humanitarian or security lens that obscures these critical but 
politically charged aspects of how peace must be built. In turn, Peace building often proceeds as if there is no significant need to restructure the local state. The failure to do so, and thus create mistrust in state institutions to deliver law fairly, often means locals rely on traditional or informal mechanisms with mixed results and contradictory effects

(Van Tongeren, 2012), argued that although informal peace committees are effective and sustainable, participants strongly stressed that they often do not have the capacity to deal directly with political level conflicts. Using their experiences in Zimbabwe, they stressed that this limitation is especially noticeable during election time when political polarization in communities takes centre stage. He observed that even peace committees formed mainly of members of different political parties are often found wanting during election times. He summed it up by saying that this paralysis is mainly due to the fact that these types of conflicts are usually instigated from outside of the community by people at a higher level within the political formations involved, such that the local political functionaries merely follow orders. Yet the lower level social conflicts that the local peace building formations often deal with contribute to the political stability or otherwise of the community as they are the fodder on which the political polarization feeds. Thus the more effective they are at the lower levels of social interaction and relationships the more relevant their work becomes at the higher levels in the community.'

(ZIMCET, 2014), identified limitations of informal peace committees and how they differ significantly from those identified by participants. In the literature, it was demonstrated that informal peace committees face collapse because of lack of funding. A classic example in Zimbabwe was the Zimbabwe Civic Education Trust (ZIMCET) peace committee programme, which survived a near collapse because of lack of funding until Oxfam America and other well-wishers rescued the organization in 2003. From this example, it was clear that peace committees that run on funded programs were at risk as some members participate based on what they will get out of the peace programme rather than what they are likely to contribute, To mitigate this limitation, support should be offered to self-initiated peace committees to ameliorate their legitimacy. (Sangqu, 2014) observed that another limitation facing informal peace committees was that they are restricted in taking part in the peace process pointed out that peace processes have been largely dominated by the elites who include political leaders and international stakeholders. She noted that, currently, informal peace committees were situated to address the softer aspects of peace process including reconciliation, forgiveness and healing related issues and concluded that such a position has ripple effects on the critical role of local peace committees in peace building. However, she contended that while peace processes cannot be left to political elites alone, and noted that local peace committees should not play a subordinate role but should actively collaborate in the peace process. Further, she recommended that attempts should be made by elites to give space to local peace committees to participate actively in the entire peace process but warned that informal peace committees should operate independent of elites, if trust, legitimacy and social cohesion are to be harnessed.

(Odendaal, 2010), observed that in addition, in some countries such as Zimbabwe, informal peace committees did not have any legal framework because their establishment followed an informal model in which people at the grassroots were involved in setting up the initiative. In such a context, the challenge is that informal peace committees do not enjoy official recognition from the state and therefore they often suffer setbacks in terms their inclusion in mainstream peace building. Another limitation is that of power dynamics associated with peace committees in their host communities. (Adanet.al, 2006), noted that if the community is male-dominated, the composition of the peace committee will be influenced by these gender dynamics, thus posing a challenge to gender representation on the committee. He pointed out that, although peace committees drew much of their approaches from both customary and cosmopolitan norms and values, the challenge is traditional practices that have not been opening up, especially in those areas involving the inclusion of women, youth and political leaders. The exclusion of women and youth serves only to reinforce the patriarchal system in communities, which embraces tradition.

According to (Oberschall, 1973), understanding the nature of conflict, its causes and means of resolution have occupied academic disciplines for much of the 20th century. The study has provided a review of some of the literature on conflict. It aims to synthesize some of the major theoretical arguments on how conflict can be defined, how it is structured and why it develops. The study of conflict does not sit happily within any one academic discipline and in fact each discipline adopts a slightly different treatment of the issue. At a very basic level sociologists see conflict as a function of social structure and an inimical part of the way society evolves. Political science sees conflict as a function of power relations, Marxist and Gramscian thought would see class struggle as the root cause. Economists on the other hand regard conflict as the result of rational decision making by an individual seeking to maximize their personal utility given a pool of scarce resources and might even contest that conflict and competition were one and the same.

According to (Wallace, 1993), conflict is not only a complex issue, but the wide variety of views on the subject from a wide range of disciplines further complicates the picture. Much of the literature on conflict, as a result, tends to draw its support from the three major social sciences namely sociology, politics and economics. The study doesn't attempt to distinguish the correct discipline for analysis, rather to analyze the contradictory and complementary theory offered by the disciplines for the study of conflict.

\section{THE RESEARCH PROCESS}

The overall objective of this study was to evaluate the strategies employed by informal peace committees in peace building in Nairobi County using descriptive methodology. This design was considered relevant in relation to the study objectives. The design helped the study achieve its research purpose of describing, explaining, and validating the findings. It was particularly important in linking research with actions that bring the social, political and economic change. The participants were observed in their natural environments without interfering with their activities and behaviors. This allowed for a multifaceted approach to data collection and analysis.

The design chosen involved measurement, classification, analysis, comparison and interpretation of data. In this method, 
information was obtained using questionnaires, focus group discussions and interviews to a sample of individuals selected randomly rather than the entire population. The study population comprised of eight categories of respondents, those from the political class, professionals, business community, peace committee members, religious leaders, government officials, civil society, and finally, the women and the marginalized groups. The tabulation of the study population is made in Table 1 sampling frame of the study population

Table 1 Sampling frame of the study population

\begin{tabular}{|l|l|}
\hline Category & Target population \\
\hline peace committees members & 330 \\
\hline Political Leaders & 244 \\
\hline Women and the marginalized groups & 595 \\
\hline Business community & 600 \\
\hline Professionals & 60 \\
\hline Religious leaders & 95 \\
\hline Government officials & 156 \\
\hline Civil society officials & 80 \\
\hline $\begin{array}{l}\text { Libraries, repositories, published works, journals, } \\
\text { databases }\end{array}$ & \\
\hline TOTAL & 2160 \\
\hline
\end{tabular}

Given that the study population was high, the study developed a sampling frame where a list of all the respondents relevant to the study was made. To accomplish this, the study was based on a target population of 2160 respondents, and a sample size of 509. Simple random sampling was used in all the 85 wards in Nairobi County to extract the samples in all eight categories. Simple random sampling was considered unbiased, inclusive and each unit had an equal chance of being included in the sample (Benedetti, et al, 2010).

Table 2 Summary of the sampling method

\begin{tabular}{|c|c|c|c|c|}
\hline Category & $\begin{array}{l}\text { Target } \\
\text { population }\end{array}$ & Sample proportion & Sampling method & Sample size \\
\hline peace committees members & 330 & 75 & $\begin{array}{ll}\text { Simple } & \text { random } \\
\text { sampling } & \end{array}$ & $22.7 \%$ \\
\hline Political Leaders & 244 & 51 & $\begin{array}{l}\text { Simple random } \\
\text { sampling }\end{array}$ & $20.9 \%$ \\
\hline $\begin{array}{ll}\text { Women and the } \\
\text { marginalized groups }\end{array}$ & 595 & 142 & $\begin{array}{ll}\text { Simple random } \\
\text { sampling }\end{array}$ & $23.9 \%$ \\
\hline Business community & 600 & 148 & $\begin{array}{l}\text { Simple random } \\
\text { sampling. }\end{array}$ & $24.7 \%$ \\
\hline Professionals & 60 & 13 & $\begin{array}{l}\text { Simple random } \\
\text { sampling }\end{array}$ & $21.7 \%$ \\
\hline Religious leaders & 95 & 21 & $\begin{array}{ll}\text { Simple random } \\
\text { sampling }\end{array}$ & $22.1 \%$ \\
\hline Government officials & 156 & 40 & $\begin{array}{l}\text { Simple random } \\
\text { sampling }\end{array}$ & $25.6 \%$ \\
\hline Civil society officials & 80 & 19 & $\begin{array}{ll}\text { Simple random } \\
\text { sampling }\end{array}$ & $23.8 \%$ \\
\hline $\begin{array}{l}\text { Libraries, repositories, } \\
\text { published works, journals, } \\
\text { databases }\end{array}$ & & & & \\
\hline TOTAL & 2160 & 509 & & $23.6 \%$ \\
\hline
\end{tabular}

Source: Author (2018)

The sample size comprised of 51 Political leaders representing $20.9 \%$ of the target population, 75 Peace committee members representing $22.7 \%$ of the target population. 40
Government officials representing 25.6\%, 19 Civil society officials representing $23.8 \%$ of the target population, 13 Professionals representing $21.7 \%$ of the target population, 21 Religious leaders representing $22.1 \%$ of the target population, 148 
Members of the business community representing $24.7 \%$ of the target population, 142 Women and marginalized groups including the youth representing $23.9 \%$ of the target population. According to (Kothari, 2009), when the population is more than 10,000 participants, the formula below can be used to calculate the target population:

The sample size was computed using the formula:

Where;

$$
n=\frac{z^{2} p q}{e^{2}}
$$

$\mathrm{n}=$ the desired sample size (if the target population is greater than 10,000)

$\mathrm{z}=$ the standard normal deviate at the required confidence level of $99 \%=2.58$

$\mathrm{p}=$ the proportion in the target population estimated to have characteristics being measured estimated at 0.5

$\mathrm{q}=1-\mathrm{p}$

$\mathrm{d}=$ the level of statistical significance set at 0.05

This gives $n_{0}=666$. Since the target poplation was 2160 the adjusted sample size was obtained using the formula

$$
n=\frac{n_{0}}{1+\frac{\left(n_{0}-1\right)}{N}}=\frac{666}{1+\frac{(666-1)}{2160}}=509
$$

The study was based on a sample population of 509 respondents, out of a study population of 2160 . The sample was distributed as follows;

These were the samples used in the collection of data in order to provide the information required. This represented a small portion taken from the larger population. This had sufficiently surpassed the minimum threshold sample size recommended by Gay (2005) that a sample size of the target population is regarded as adequate for small population $(\mathrm{N} \leq 1000)$ Mugenda, (2008). According to Kothari, (2009), when the population is more than 10,000 participants, the formula below was used to calculate the target population. The study had therefore sufficiently surpassed the minimum threshold sample size recommended by Gay (2003)

Where;

$$
n=\frac{z^{2} p q}{e^{2}}
$$

$\mathrm{n}=$ the desired sample size(if the target population is greater than 10,000)

$\mathrm{z}=$ the standard normal deviate at the required confidence level

$\mathrm{p}=$ the proportion in the target population estimated to have characteristics being measured

$\mathrm{q}=1-\mathrm{p}$

$\mathrm{d}=$ the level of statistical significance set.

$\mathrm{Z}^{2}=2.58<$ if $\square=0.05>$ level of significance

This means that the response rate may affect the number of people you send your survey to. The higher the response rate, the fewer people you need to ask to take your survey.

The study employed several data collection instruments including, questionnaires, interviews, focus group discussions as primary sources while repositories, peace and conflict journals and databases formed part of the secondary data collected. The questionnaires were administered to the women, youth and the marginalized groups, and the business community where primary data was collected. However, the questionnaires were not conclusive in gathering the data required and therefore, the need for other methods. The study considered interviews as key qualitative data collection method for the collection of primary data. There were many reasons for the use of interviews in the collection of data as a research instrument. First, they were mainly useful in attaining highly personalized data, as well as providing the opportunities for probing to get underlying factors, and also became a viable option where there were limited respondents.

The main advantage of the interviews stemmed from their capability to offer a complete description and analysis of the research subject, without limiting the scope of the research and the nature of participant's responses. The Interviews were thus useful for gaining insight and context into the research topic. From the onset, the interviews facilitated the accurate screening for the right interviewee while seeking complete description and analysis of the subject matter. The interviewer sought the right individuals who had the desired information. While the interviews enabled the study to reach the limits of the interviewee's knowledge, it encouraged co-operation and helped to establish rapport. The interviews targeted the political leaders, government officials and the civil society officials.

Focus Group Discussion (FGD) was used a method of data collection to collect primary data. The main goal of Focus Group Discussion was to provide an opportunity for the participants to talk to one another about the study topic where the facilitator/researcher guided the discussions. The focus group discussions involved members of the informal peace committees, nyumba kumi initiative members and the local administrators mostly chiefs and assistant chiefs. The study had five focus group discussions in five different constituencies drawn across Nairobi County. The focus group discussions were mainly held in chief's office and comprised not more than twelve members in any one sitting. I collected secondary data from Libraries, repositories, published and unpublished works, journals, and databases on peace building. Secondary data provided a baseline for primary research in comparing the collected primary data results and it was also helpful in research design.

Data analysis was guided by the research objectives presented. The study generated both quantitative and qualitative data. Descriptive statistics data analysis method was applied to analyze numerical data gathered using closed ended questions. Qualitative data analysis was conducted using content analysis which classified, summarized and tabulated the data while quantitative data analysis included calculation of frequencies of variables and differences between them in order to support or reject. A model was deemed to be significant if the overall p-value was less than 0.05. Further tests on the contribution of the individual factors were concluded. The influence of a factor was concluded to be significant if the associated p-value was less than 0.05

Likert type scale items were analyzed on whether they were favorable or unfavorable. Those favoring the argument was analyzed using the order that depicted strongly agreed (SA) as having the highest weight and strongly disagreed (SD) having the least weight. For items that did not favor the argument analysis was done in reverse order where strongly disagreed (SD) had the greatest weight and strongly agreed (SA) least weight. Inferential 
data such as charts and frequency tables were basically applied in the presentation of findings by use of SPSS in all objectives.

\section{Results and Discussions \\ Capacity to deal directly with political level conflicts}

The respondents' opinion was sought on whether informal peace committees faced the challenge while dealing directly with political level conflicts in Nairobi County. The respondents' opinion was .Table 1 summarizes the findings.

\section{Table 1 Lack capacity to deal directly with political level conflicts}

\begin{tabular}{lll}
\hline Response & $\mathbf{N}$ & $\mathbf{\%}$ \\
\hline Less than & 24 & 5 \\
$10 \%$ & & \\
$11-25 \%$ & 42 & 8 \\
$26-50 \%$ & 50 & 10 \\
$51-70 \%$ & 201 & 39 \\
$76-100 \%$ & 192 & 38 \\
\hline Total & $\mathbf{5 0 9}$ & $\mathbf{1 0 0 . 0}$ \\
\hline
\end{tabular}

Source: Field Data (2018)

The findings in Table 1 showed that the majority of the respondents strongly agreed that informal peace committees faced the challenge of dealing with political level conflicts in Nairobi County. The number agreeing that informal peace committees faced the challenge in dealing with direct political level conflicts in Nairobi County was 393, representing (77\%), while those with different opinion were 116, representing (23\%). Political level conflicts was understood to mean the activity by which differing interests within a given unit of rule are conciliated by giving them a share in power in proportion to their importance to the welfare and the survival of the whole community

\section{One informant from the FGD observed argued:}

Although informal peace committees are effective and sustainable, they face serious challenges to deal with political level conflicts'. This is attested by past experience of post election violence in 2007/2008 and previous general elections in Kenya. The limitation was especially noticeable during election time when political polarization in communities took centre stage. This was due to high levels of ethnicity, informal peace committees found it very difficult to deal with polarization brought about by ethnicity.

The observation highlighted complex nature of conflict resolution while dealing with politically motivated conflicts. It emerged that although informal peace committees were able to prevent possible conflicts, to a certain extent the political leaders were able to water down their gains in peace building process. It emerged that although peace building is a long process to achieve, some politicians could destroy it in minutes especially during election times. During elections, politicians used the platform to incite their tribesmen against others with the motive of trying to win their votes. However, it also emerged that informal peace committees should not take this as a challenge but an opportunity to blacklist politicians who were inciting the communities. It emerged that the informal peace committees could also rally the communities to shun politicians who were not conscious of the well being of the communities.

This position corroborated and differed with (Van Tongeren, 2012), argued that although informal peace committees are effective and sustainable, participants strongly stressed that they often do not have the capacity to deal directly with political level conflicts. Using their experiences in Zimbabwe, they stressed that this limitation is especially noticeable during election time when political polarization in communities takes centre stage. $\mathrm{He}$ observed that even peace committees formed mainly of members of different political parties are often found wanting during election times. He summed it up by saying that this paralysis is mainly due to the fact that these types of conflicts are usually instigated from outside of the community by people at a higher level within the political formations involved, such that the local political functionaries merely follow orders. Yet the lower level social conflicts that the local peace building formations often deal with contribute to the political stability or otherwise of the community as they are the fodder on which the political polarization feeds. Thus the more effective they are at the lower levels of social interaction and relationships the more relevant their work becomes at the higher levels in the community.

One informant from the professional groups observed that:

Kenya has long been considered a stable country in the East and Horn of Africa region and has since the late 1990s been making steady progress towards being a fully fledged multiparty democracy. Violence has accompanied almost every election cycle since the introduction of the multiparty political system in 1991. The violence following the December 2007 general election was the worst. . During the five year election cycles since 1991, there has been polarization in communities which has had a negative impact. The Kenyan economy has suffered while community's ability to integrate and cohese together has seriously been affected. This has been occasioned by the political class who has been the biggest obstacle in the progress of integration and reconciliation of the Kenyan communities. Informal peace committees are unable to deal directly with political level violence as they are unable to take control by ensuring that politics did not divide the communities along tribal lines.

The observation added to the protracted academic debate on the analysis of democracy and development. It emerged that although democracy has been hailed for positive things, it was argued that democracy to a certain extent was misleading. It emerged that when there is too much freedom, some people misuse it for their own benefit. It emerged that most of the violence/conflict witnessed in Nairobi County has been witnessed since the introduction of multiparty democracy. It emerged that while democracy has opened the political space, it had its own shortcomings. Some politicians were using the freedom of speech to incite communities against other political opponent. However, some sections of the participants also felt that communities had failed in their obligation to hold politicians to account through the electoral channel just like other developed nations have done.

This position was in agreement with (Goetz and Jenkins, 2005) who argued that as analysts have found, relying on a minimalist definition of democracy cannot quite capture the 
challenges besetting regimes that have undergone a transition but have yet to consolidate their incipient democratic structures. As a result, a growing number of democratization experts are turning towards a more substantive definition of democracy, one that gives greater prominence to the role and importance of accountability. Three dimensions of accountability are usually distinguished:(i) vertical accountability, which enables citizens to hold their political leaders to account through the electoral channel at specified points in time; (ii) horizontal accountability, which refers to accountability mechanisms that exist within the distinct bodies of government itself, whereby state institutions are authorized and willing to oversee, control, redress and, if need be, sanction unlawful actions by other state institutions (O'Donnell 1996); and (iii) societal accountability, which refers to the (ongoing) watchdog functions of civic associations, other NGOs and an independent mass media over the actions of the state (Schedler et al. 1999).

An informant from the FGD observed that:

The lack of patriotism among the Kenyan citizens has been the biggest challenge to political level conflicts. The informal peace committees have not succeeded in promoting patriotism among Kenyan societies. This in effect has given the political class an opportunity to exploit the gap. The only cure to this phenomenon lies in the ability for the informal peace committees to scale their peace education programs especially to the youths on patriotism. Our forefathers were able to deliver our country from the yokes of colonialism due to their patriotism on their beloved country.

It emerged from the discussions that the biggest challenge to peace building in Nairobi County was the lack of patriotism. Most communities owed their loyalty to their ethnic tag at the expense of National fabric. The lack of National patriotism where citizens valued their Nationality rather than their ethnic background was the biggest undoing to peace building in Nairobi County. It emerged that although Kenya has symbols of National unity, little attention was given to educate the citizens the benefits of National patriotism. This shortcoming was exploited the political class to divide Kenyans and in particular Nairobians along tribal lines. It emerged that both peace educators and leaders in general had failed the test of entrenching patriotism as a culture in Kenya and in particular Nairobi County.

This statement corroborated with (Korostelina 2013), who observed that as agents of peace, peace educators are expected to model interpersonal relationships and teach/impart values which uphold peace including tolerance, recognition and respect and a range of skills such as critical thinking, compromise, mediation and collaboration. Teachers are not always considered positively in terms of peace building, if anything the evidence illustrating their role in stoking conflict or preventing 'progressive' reform appears to be more plentiful than the literature advocating their positive contributions to peace building. For example the literature contains examples of teachers manipulating nation building aspects of the curriculum such as History or Geography to represent their own biases and views of history, constructing allies and enemies from their own perspective and re/producing national narratives (of teachers reproducing and normalizing unequal gender relations, and of schools as the sites of physical violence (sexual exploitation and corporal punishment)
An informant from the civil society observed that:

The informal peace committees can overcome the challenge of dealing with political level conflicts by lobbying political actors and creating a platform where politicians would be required to observe peace before and after elections. This will ensure that they don't polarize relationships between communities as they compete for political office. If the informal peace committees are able to win the hearts of the communities through outreach, they would be in a position to overcome the challenge of dealing with political level conflicts

The sentiments highlighted the complexity that is required to understand why and how to end conflict, violence, and war and to keep the peace. It emerged although informal peace committees felt the challenge of dealing with political level conflicts; they had not exploited the opportunity to hold politicians accountable for their actions. It emerged that informal peace committees could team up with civil society organizations in a movement to make politicians account for their actions. This would ensure that the political class sign peace pacts with the citizens before vying for any political office.

The sentiments corroborated with Fisher's (1969), who noted that peace occurs along many dimensions and at many levels. Recognizing this complexity is required to understand why and how to use conflict, violence, and war to keep the peace. To fight something by deliberately introducing that which one wants to avoid certainly is paradoxical, at first thought; and initially, selective burning to control forest fires, inoculation to prevent disease, and herd-thinning to prevent mass starvation were not readily accepted concepts. Fisher argued that to maintain a higher peace may entail lower-level conflict in order to make needed readjustments of expectations and power. Such conflicts through time further a process of adaptation to change. This helps avoid that large gap between the balance of powers and status quo that requires an adjustment possible only through much more extreme conflict and violence. As such, enabling such continual adjustments through nonviolent conflict is one of the values of the exchange society and libertarian political system--that is, of the just peace. And a corollary is that it is often better to let conflict take its course, for parties to negotiate their own balance, than for a third party to impose an artificial peace simply in order to avoid conflict.

The statement further corroborated with (Sen, 1999), who argued that democracy should not be expected to produce better socio-economic outcomes simply because it is a democracy. As Sen, and many others have argued, the democratic process does have intrinsic value on its own right, and it should be expected to arrive at policy decisions in a way that is inclusive, participatory, broadly representative of different societal interests, transparent, and accountable. In particular, following the Sen tradition, the importance of participation in one's development through open and non-discriminatory democratic processes is fundamental. Once the intrinsic value of democracy has been established, however, it is still very much worth asking the 'so what' question: does democracy make a difference, and if so, what kind of difference? The growing recognition of institutions as key factors in shaping (developmental) outcomes and the movement of more poor countries toward democracy have both sharpened the relevance and the stakes of this debate even further. 


\section{DIFFICULTIES ENFORCING DECISIONS ARRIVED AT PEACE AGREEMENTS.}

The informants were asked whether informal peace committees were challenged in enforcing decisions arrived at peace agreements. Table 3 summarizes the findings.

Table 2 Difficulties enforcing decisions arrived at peace agreements

\begin{tabular}{lll}
\hline Response & $\mathbf{N}$ & $\mathbf{\%}$ \\
\hline Less than & 30 & 6 \\
$10 \%$ & & \\
$11-25 \%$ & 40 & 8 \\
$26-50 \%$ & 107 & 21 \\
$51-70 \%$ & 155 & 30 \\
$76-100 \%$ & 177 & 35 \\
\hline Total & $\mathbf{5 0 9}$ & $\mathbf{1 0 0 . 0}$ \\
\hline
\end{tabular}

Source: Field Data (2018)

The findings in Table 3 showed that the majority of the respondents strongly agreed that informal peace committees were not able to enforce decisions arrived at peace agreements. The number agreeing that informal peace committees were not able to enforce their decisions arrived at peace agreements was 332, representing $(65 \%)$, while those with different opinion were 177 , representing $(35 \%)$.

An informant from the civil society observed:

Successful peace agreements are anchored on leaders honoring their commitments. This was the case in the South African, Namibian, and Mozambican peace processes. However, such committed leadership cannot be assumed. For example, in Lesotho, Burundi, and DRC, political leaders methodically dismantled key elements of the agreements that they saw as impediments to their pursuit of power. Regional and international partners, in turn, failed to enforce the peace processes' provisions when these were being violated. This underscores the indispensable role that external guarantors play in the years after an agreement is signed. This is more than a perfunctory responsibility. The role of informal peace committees especially in Nairobi County to enforce agreements arrived at peace agreements is questionable. They do not have a mechanism to enforce those agreements they participated in negotiating.

The sentiments highlighted the premium attached to peace implementation process that would make it long lived. It emerged that negotiating and signing peace agreements seemed achievable, but the elephant in the room is the implementation. Most countries have negotiated and signed peace agreements but have not able $t$ implement the same. It was argued that in most conflict cases, the warring parties will negotiate and sign a peace agreement only to disown the agreement at some point. It emerged that the disconnect was mainly from dishonest leadership that would sign the pact to favor them and disown the same when it did not favor them

This publication is licensed under Creative Commons Attribution CC BY

http://dx.doi.org/10.29322/IJSRP.10.10.2020.p10662
The remarks corroborated with (Ayoub Mona, 2006), who noted that the failure of peace agreements has been explained by negotiated settlements tending to be used in more intractable armed conflicts; thus, making them more short-lived Moreover, peace agreements fail due to the challenge of implementation. Peace implementation is a high-stake transition process with uncertainty, intangibles and set-backs. In these circumstances, it is difficult to maintain the commitment of belligerents and thirdparties to a peace process. Belligerents are often unable to create credible commitments to disarm and demobilize. Peace implementation is also challenged by disproportionately influential groups having the resolve, opportunity and capability to spoil an agreement finally, if the conditions for rebel recruitment in a post-conflict period remain unchanged, armed conflict is likely to recur

An informant from the professional group who observed that: Informal peace committees are not able to enforce peace decisions arrived at peace agreements. This is especially because, political elites have a tendency to challenge new norms and revert to entrenched legacies of malpractice. Institutional strengthening and robust oversight are fundamental ingredients in the success of peace agreements. Yet, nearly all countries emerging from conflict have weak institutions. Peace agreements, therefore, must be explicitly bolstered and protected against anticipated executive branch interference. In short, domestic political actors will want to test these limits. Experience shows that clear responses from guarantors to these tests are warranted to keep peace processes on track. However, informal peace committees can engage and lobby political class to honor their word in peace building processes.

The remarks emphasized on the structures that help identify, strengthen, support and solidify peace process. It emerged that for peace agreements to be implemented successfully, there is need for setting institutional reforms that will be given specific responsibilities in the implementation stage. It emerged that after the post election violence of 2007/2008 in Kenya, a National accord was negotiated and signed which later paved way for the new constitution in 2010 . The promulgated new constitution had very elaborate institutional structure that ensured that the items negotiated were captured and specific institutions were set to ensure the implementation process. A good example of the institutions was the constitutional implementation commission which had a five year mandate to ensure full implementation of the constitution. The onus was therefore for the informal peace committees to partner with other players to put government on check

The observation affirmed (Schwarz Rolf, 2005), who stated that the recurrence of armed conflict underlines the importance of the relationship between peace agreements and peace building. Post-conflict peace building is a comprehensive strategy to assist areas of armed conflict in their transition from war to peace. It is defined as an "action to identify and support structures which tend to strengthen and solidify peace in order to avoid the relapse into conflict. Peace building ultimately is state-building in which the main functions of the state - security, welfare and representation - are created through external assistance and domestic ownership . Schwararz Rolf noted that the key question for the relationship between peace agreements and peace building is if the type, content and quality of peace agreements promote the sustainability 
of peace building. Peace building is part of the continuum of conflict management strategies. It is preceded by a mediation process, a peace agreement, and humanitarian relief or peacekeeping operations. As peace building comes at a later stage of conflict management, it inherits flaws from previous phases. Peace building therefore looks backward to implement what has been agreed before and at the same time forward to prevent future armed conflict.

Another informant from the religious group remarked:

The informal peace committees are not entirely to blame for lack of enforcement in decisions arrived at peace agreements. Peace agreements will require strong protections of civil liberties where civil society and the media play a critical role in providing domestic oversight and upholding institutions it will never work. Restrictions on civil society and the media, therefore, should be an early warning signal to external actors of threats to the implementation of the peace process. Protections of civil liberties should be accompanied by clearly defined and strict term limits for political leaders. Such limits are especially important in these early years when norms of succession have not yet been established and restraining institutions are weak. Successful consolidation of peace agreements takes time. Early progress is not a guarantee of long-term success. Sustaining the peace process relies on resilient institutions; success requires ongoing engagement by domestic, regional, and international actors. This consolidation process typically requires at least a decade. Regional enforcement through collective action may appear cumbersome. However, as the cases cited above show, inaction opens the seam for the unraveling of the rest of what may be a well-knit peace agreement. The cost of this inaction, moreover is invariably higher for the designated country and its neighbors.

The observation highlighted the challenges of not protecting peace agreements which is required to protect civil liberties where civil society and the media play a critical role in providing domestic oversight. It emerged that after setting institutional structures to ensure full implementation of the peace agreements, there was need for a vibrant civil society and trusted media house to keep the government on toes in the implementation stage. It emerged that in situations where the government gagged the media and the civil society, implementation of peace agreements was either slow or did not take off. In the same vein, the informal peace committees must join hands with the civil societies to push for full implementation of negotiated peace agreements.

The sentiments corroborated with (Westphal Florian, 2004), who observed that internal conflicts do not occur spontaneously but tend to have a history. Local media usually have a deeper understanding of the existing political structures, the participants of the conflict as well as the changes preceding the outbreak of violence. The media can therefore not only influence society before the conflict by recognizing and properly addressing the issue but also afterwards. Unlike international media covering conflicts, local media are a recognized part of society with the ability to accelerate and magnify fears or reduce them. One should not forget that journalism can play a role in escalating conflicts, which also demonstrates the potential for positive purposes. The media have the power to defuse tensions before they even reach a critical point and keep a critical eye on government, opposition and society. By supplying credible information and reaching a large audience, the media help in managing conflicts and promote democratic principles. In the aftermath of a conflict, reconciliation and societal development can be encouraged as well.

An informant from the government official observed that:

Despite the commendable efforts accredited to informal peace committees, they have not been spared of avalanches of challenges. They Lack legal and policy framework to secure their work. The biggest challenge for informal peace committees in Nairobi County has been the absence of legal and policy framework. They are thus regarded as ad hoc illegitimate arrangements to prevent communal conflicts. This challenge has been exploited by any clever criminal or person who can successfully challenge the existence and any ruling of peace committees in a court of law. Again, they have also not been spared by the government of the day because there has not been any policy framework to officially recognize their existence.

The sentiments expressed the challenges of missing or lack of policy and regulatory framework to guide the operations of the informal peace committees. It emerged that the fact informal peace committees did not have an elaborate policy and legal framework; it did not in any way stop them from being recognized by the government. This was considered as an excuse that could not hold any water, instead it emerged that they had to prove their relative worth for them to be taken seriously by other players including the government. These sentiments were echoed by (Odendaal, 2010) who noted that informal .peace committees do not have any legal framework because their establishment followed an informal model in which people at the grassroots were involved in setting up the initiative. In such a context, the challenge is that informal peace committees do not enjoy official recognition from the state and therefore they often suffer setbacks in terms their inclusion in mainstream peace building

An informant from the marginalized group observed that:

The lack of legal and policy framework to straighten the operations of informal peace committees has a serious challenge. This means that they lack the authority to impose sanctions especially to the criminal networks operating in the slums of Nairobi County. Criminals have gone scot free because of this loophole. In most slums in Nairobi County, criminal gangs have forcefully occupied houses in the slums and evicted the legal owners of those houses. Informal peace committees have been unable to enforce the rules and return the houses to their original owners.

The sentiments expressed the challenges of missing or lack of policy and regulatory framework to guide the operations of the informal peace committees. This challenge did not go without being discredited. It emerged that the informal peace committees had a responsibility to prove their relative worth for other actors and player's to recognize and appreciate their work and thereby give them formal recognition. It was argued that the informal peace committees had to put their house in order before seeking formal recognition. It also emerged that, informal peace committees should strive to demand full recognition from government since the same government was aware of their existence which proved that they were operating within the legal framework. The observation affirmed the words of (Bush, 2004), who observed that the strength of informal peace committees is 
the local initiative and local ownership. These are priceless ingredients of any peace building process. Bush stated: Peace building is not about the imposition of solutions, it is about the creation of opportunities'. The challenge is to identify and nurture the political, economic, and social space, within which indigenous actors can identify, develop, and employ the resources necessary to build a peaceful, prosperous, and just society. Informal peace committees rely on the initiative and commitment of local actors are clearly closer to this ideal than processes that have been designed at national level

An informant from the religious group observed:

Informal peace committees face the challenge of not being recognized formally by the state away from the national cohesion and integration commission. This can be achieved through lobbying parliamentarians to enact laws to officially recognize their existence in law. This would ensure that they are able to carry out their functions and activities without the challenge of enforcing their decisions arrived at peace agreements.

The remarks highlighted the challenges and opportunities available faced by informal peace committees through legislation to bring national peace accord. It emerged that in as much as informal peace committees would negotiate peace agreements, their resolution could be disowned for lack of loci standi in law. In other words, the resolutions could not be binding in law and could not be enforced. This loop hole has been used by criminals who know the legal flaws to beat justice. This affirmed (Adan \& Pkalya 2006), who observed that there are two main categories of local peace committees. There is one that enjoys formal state recognition and the other that has informal status. Informal peace committees with formal state recognition are usually those created through a national peace accord, legislation or a formal statutory body as part of its mandate. Examples include informal peace committee in South Africa which was established following September 1991 terms of reference of the national peace accord, district code of conduct monitoring committee in Sierra Leone which was created by the political parties registration commission with responsibility or statutory mandate to mediate conflicts between political parties in addition to promoting pluralism, and the committees on inter-community relations in Serbia created under the terms of the law on local self-government of 2002, Act 63

\section{CAPACITY TO RECONCILE DIVIDED COMMUNITIES}

The respondents were asked whether informal peace committees faced the challenge of reconciling divided communities in Nairobi County. Table 5 summarizes the findings.

Table 3 Capacity to reconcile divided communities

\begin{tabular}{|c|c|c|}
\hline Response & $\mathbf{N}$ & $\%$ \\
\hline Less than & 7 & 1 \\
\hline $10 \%$ & & \\
\hline $11-25 \%$ & 80 & 16 \\
\hline $26-50 \%$ & 97 & 19 \\
\hline $51-70 \%$ & 103 & 20 \\
\hline 76- $100 \%$ & 222 & 44 \\
\hline
\end{tabular}

This publication is licensed under Creative Commons Attribution CC BY http://dx.doi.org/10.29322/IJSRP.10.10.2020.p10662

\begin{tabular}{lll}
\hline Total & 509 & 100.0 \\
\hline
\end{tabular}

Source: Field Data (2018)

The findings in Table 6.5 showed that the majority of the respondents strongly agreed that informal peace committees faced the challenge of reconciling divided communities in Nairobi County. The number agreeing that informal peace committees faced the challenge of reconciling divided communities in Nairobi County was 325 , representing $(64 \%)$, while those with different opinion were 184, representing (36\%). Reconciliation was understood to mean the process of restoring traumatized relationships between the victim and the offender. Reconciliation was also understood as overcoming hostility and conflict between individuals and divided ethnic communities. Reconciliation meant open and shared acknowledgement of the injuries caused and the losses experienced. It is one thing to strive to know something, but another to acknowledge it

(Hayner, 1996), defined reconciliation as being constituted by both a focus and a locus, the focus of reconciliation is upon building new and better relationships between former enemies. Relationships are both the root cause and the long term solution of conflict. The relationships must be the core focus. As a locus, He argued that reconciliation represents a space, a place or location of encounter, where parties to a conflict meet. In this place, the traumas of the past and the hopes for the future must be formulated and brought together by discussing the issues of truth, forgiveness, justice, and peace. (van der Merwe, 1998), pointed out that reconciliation must meet all initiatives which bring together, or engage, both sides in a pursuit of changing identity, values regarding interaction, attitudes, and patterns of interaction that move them to a more cooperative relationship. He investigated reconciliation from three dimensions: the spheres of relationships concerning identity, values, attitudes and behavior, the substantive components of reconciliation (justice, truth, healing and security), and the social levels of reconciliation (national, community and individual). He argued that reconciliation is a significant component in every phase of the peace-building process.

An informant from the professional group observed that:

Informal peace committees are faced with a serious challenge of reconciling communities that have had conflict before. The deep rooted enmity caused by a variety of issues relating to inequalities in social, political and economic status. The high levels of poverty have not made things any better. This has made it very difficult for the part of informal peace committees to effectively reconcile communities. However, all is not lost for them because they have a duty and responsibility to champion and advocate for equality and equity in distribution of national resources.

The remarks elaborated the challenges and weakness of lack or absence of reforms to address structural issues that led to prior violations including: individual and community reparations. It emerged that social inequality is usually associated to an unequal distribution of resources and, therefore, it is related to the gap between the rich and the poor. It also relates to an unequal access to opportunities or benefits from economic activity. In the best case scenario, this unequal distribution is associated to talent 
or effort; but, in most cases, it is the result of institutional structures that create social barriers based on: sex, age, ethnicity, social status, among other variables that define individuals' initial conditions. It emerged that although the new constitution in Kenya has tried to address the imbalances, it will take several years before the impact is felt.

The statement corroborated with Morocco's long journey to transitional justice and reconciliation where after decades of abuses committed by the government, Morocco began to undertake a multi-stage political reform process in the country. This process, through which reconciliation became part of the public discourse, included granting amnesty to political prisoners and the return of the forcibly, disappeared; creating an arbitration body to grant reparations to victims; and establishing the Equity and Reconciliation Commission (IER). A number of different measures have contributed to reform, including: individual and community reparations; history and memory initiatives; addressing structural issues that led to prior violations; and the reestablishment of trust between citizens and the state. Reconciliation in Morocco at one level has involved a sociopolitical process, through the creation of a political community based on democratic values. Contributing to this was the acknowledgement of the country's social and cultural diversity in formal processes. At another level, reconciliation has involved reestablishing trust between citizen and state institutions, further emphasized by civil society activism.

An informant from the religious group observed that:

The informal peace committees have not been able to advocate for repentance on the part of aggressors so that the victims can reciprocate by forgiving them. While the past has refused to lie down quietly, it has an uncanny habit of returning to haunt. However painful the experience the wounds of the past must not be allowed to fester. They must be opened. They must be cleansed. And balm must be poured on them, so they can heal. This is not to be obsessed with the past. It is to take care that the past is properly dealt with for the sake of the future.

The remarks highlighted the challenges associated with forgiveness which is an element of conflict resolution. It emerged that the process of reconciliation depends on the attitude of the offender, the depth of the betrayal, and the pattern of offense. When an offended party works toward reconciliation, the first and most important step is the confirmation of genuine repentance on the part of the offender. An unrepentant offender will resent your desire to confirm the genuineness of his confession and repentance. This position was affirmed by TJRC Act (2008), which stated that unfortunately, the idea that one can 'look backwards to reach forwards' downplays the complex ways in which the past actually persists, and possible futures infringe on the present. This is problematic since it can encourage a situation where small changes dampen demands for more substantive reform. At the same time, it can facilitate a politicized assertion of closure that excludes those who do not buy into the absence of the past, the newness of the present, or the desirability of imagined futures and provides a resource to those who seek to present such 'difficult people' as untrusting, unreasonable and unpatriotic. This is not to say that truth commissions are useless and should never be considered.

This publication is licensed under Creative Commons Attribution CC BY

http://dx.doi.org/10.29322/IJSRP.10.10.2020.p10662
On the contrary, many view speaking as better than silence, while the commission's report provides a historical overview of injustice in Kenya and a range of recommendations that activists and politicians are using to lobby for justice and reform. However, when introduced, truth commissions should be more aware of the importance of persuasive performances and how their initial reception and longer-term impact is shaped by broader socio-economic, political and historic contexts. Truth commissions also need to adopt a more complex understanding of the ways in which the past persists, and possible futures infringe on the present and avoid easy assertions of closure.

One informant from the religious group observed that:

The informal peace committees have the capacity to reconcile protagonist by having various events and forums that can be used to bury the hatchet. While communities come together, they are able to build trust amongst them. There are several activities that they can use to help communities build peace for example, sports. The overall objective is to bring confidence and trust among communities.

The observation highlighted the opportunities available for informal peace committees by use of unique tools used in promoting peace including sports, dialogue for peace, empowerment for peace, arts for peace or advocacy for peace. From the discussions, it was clear that sport for reconciliation projects can be used to promote social inclusion breaking down barriers and creating bridges between opposing groups. Sport can help the process of reconciliation building confidence and trust among diversity advancing healing process, encouraging resiliency, and giving a sense of normalcy. But Sport its self is not good or bad, it is just an empty and neutral box to be filled in and a tool to be used with values, ideas, meaning, dependent on the cultural context in which takes place and people who take part.

The statement differed with earlier observations that informal peace faced challenges while reconciling communities. On the contrary, the informal peace committees have not seized opportunities available to help them reconcile communities using peace tools. According to (Hoglund, K. and R. Sundberg, (2008), who analyzed the case of South Africa and its experiences in the use of sports in promotion of social solidity as part of overcoming civil conflict especially in the apartheid era. The author discusses several processes of linking sport to reconciliation such as the utilization of symbols and symbolic acts of reconciliation like handshakes and national symbols displayed on flags and sporting uniforms. Tom Woodhouse (2009) highlights the importance of innovation and creativity in peace building and proposes the use of cultural tools, including sports, as a way to energizing the field of peace studies and conflict transformation

In another research conducted by (Hall, 2011), (Moreau et al, 2014) and (Spaaij, 2014), it was found that young people participating in sport programmers experienced strong feelings of group responsibility, care and camaraderie, enhanced interpersonal confidence, freedom to challenge social habits and boundaries, and enhanced feelings of belonging through embodied and emotional experiences associated with being actively involved in a sporting competition and part of a team environment. Furthermore, according to the Swiss Agency for Development and Cooperation, Sport programs implemented in the slums of 
Medellin, Colombia have resulted in a drop in criminal behavior while in Brazil, programs such as (Segundo Tempo, 2005).are expected to show children a way out of misery and violence

One informant from the business community observed that: Informal peace committees in Nairobi County have put in place fundamental aspect of reconciliation to address past grievances suffered by victims. They have addressed individual and community grievances well before they escalate to widespread violence and disputes. This has been very instrumental in ensuring that they respond to early warnings of conflict. This has allowed for healing and reconciliation to take place.

From the interview, it emerged that forgiveness is both a process and a choice, and may be both intrapersonal and interpersonal. It is a complex and enigmatic concept, hard to pin down because it can apply in different ways to different situations; not everyone experiences it in the same manner. For some, it may result in reducing a personal hurt that makes life easier; for others, it may mean reconciling with an enemy and being able to live side by side again. However, community leaders should also understand that if community members including both authorities and civilians adopt a forgiving attitude that can be a very useful public health and community-building tool. Forgiveness may require relinquishing something that was important to you, such as giving up your moral indignation, your desire for retaliation, or your attachment to being right. Yet forgiveness is useful to community building, because people who forgive tend to be more flexible and less certain in their expectations, both in how life will be or how others will treat them

This statement was affirmed by (Mathey, 2008), when he said that the fundamental aspect of reconciliation is the recognition of the grievances suffered and the damages experienced by the victims caused by the offender. He further said that truth telling breaks apart the past which had been hidden and allows healing and reconciliation to take place. He further asserts that shared truth, documenting the causes, nature, and the extent of severe and gross human rights abuses and collective violence under antecedent regimes, is a prerequisite for achieving accountability, meaningful reconciliation, and a foundation for a common future. Mathey noted that the process of healing and reconciling the memories within the communities in conflicts can be undertaken in a number of ways. It is important to recognize that memories of the past have to be transferred, so that pain and the harm sustained can be healed. Victims and offenders should reiterate their stories of the shared events and negotiate a mutual history as a step towards reconciliation. Retelling of the details of the stories can be therapeutic and allows those memories to be incorporated into the victim's life story. When the story is told in the presence of the offender, it can lead to acknowledgement, apology, forgiveness and reconnection with each other.

One youthful informant noted:

I doubt the ability of informal peace committees to reconcile protagonist and I do not know how one would reconcile with an enemy who did not even bother to seek forgiveness'. I remember how young innocent girls were raped by people best known to them during the 2007/2008 post election violence in Kenya. How were those children supposed to go back to their original homes after the displacement and live with the same people? In fact, instead of the offenders seeking forgiveness on their atrocities, they were not even remorseful on their action. It is very painful seeing those perpetrators walking scot free in the slums.

From the discussions, it emerged that forgiveness and reconciliation can occur in every sphere of human experience, including individual, community, national, and trans-national levels. In any discussion about forgiveness and reconciliation, it is important to make a distinction between the two before analyzing each of them in greater detail. On the one hand, forgiveness does not necessarily mean reconciling with the wrongdoer. There may be good reasons why you do not wish to reconcile. Reconciliation is an additional choice. On the other hand, it is nearly impossible to reconcile with someone you have not gone some way to forgive. This position was affirmed by (Wabanhu, 2008), who said that forgiveness is a precondition for reconciliation and an essential part of reconciliation as well. He further defined forgiveness in two dimensions, namely; the secular and religious meanings. From the secular meaning, $\mathrm{He}$ argued that forgiveness contains two essential elements. The first is willingness to abandon one's right to resentment, condemnation and subtle revenge towards an offender who acts unjustly. The second is willingness to foster qualities of compassion, generosity, and even love towards the offender. Thus, for them, forgiveness consists of a decrease in negative responses, and an increase in positive responses towards a transgressor.

That position was later amplified by (May, 2010), who stated that Reconciliation which overlooks or represses the quest for justice is not reconciliation at all. However, we cannot ignore the fact that reconciliation has to do with some compromises. The compromise does not have to be one-sided since this will prevent it from resolving the conflict or providing a lasting peace. This means that we cannot confuse reconciliation with compromise. Taking responsibility for an offence creates a welcoming environment for the reconciliation process. He suggested in his acknowledgment of sharing the same understanding of reconciliation with philosopher Janna Thompson, reconciliation is achieved when the harm done by an injustice to relations of respect and trust that ought to exist between individuals and nations has been repaired or compensated for by the offenders in such a way that ensures the establishing or re-establishing of these relations. The offenders need to be responsible for the harm they have caused.

An informant from the professional bodies remarked:

Informal peace committees have faced challenges while trying to address the plight of victims to get justice while restorative justice does not demand complete consensus. While democratic reciprocity is no doubt a preferred model for addressing domestic political conflicts, the reconstruction of a society following a civil war will require not only the institutions' expressed democracy but also the cultivation of national unity. If deeply divided societies, as in the case of Kenya, are to become harmonious, they need to embark on radical programs of moral, political and legal reconstruction, such as that illuminated by the restorative justice perspective. Informal peace committees are not able to provide political, moral or legal programs.

It emerged that there are specific criticisms that have been raised regarding the appropriateness and effectiveness of restorative justice programs including failure to consult with 
Indigenous communities when establishing programs, that access is a matter for police discretion, too little attention has been paid to cultural differences and the programs are seen to undermine self-determination. Once implemented, such programs in Indigenous encountered a range of issues including low referral rates, few Indigenous conference conveners, high number of youths failing to appear for conferences and a lack of awareness among the Indigenous community of the potential benefits of restorative justice.

This position differed with (Amstutz, 2006), when he stated that Restorative justice does not disregard past wrong-doing, as some of the critics allege. Rather, it seeks to confront the dire truth about the past crimes and injustices by using the truth to foment changes in values and behaviors that increase the prospects for reconciliation. From this understanding, it is important to note that justice itself is moral and ethical and not just legal. It is all about being open to discussion with the right actions to restore relationships. Restorative Justice is a demanding ethic that encourages enemies to confront their humanity and calls on offenders to disclose their accountability and victims to show empathy toward the offenders. In brief, Restorative Justice seeks to achieve idealistic personal and communal reforms so that the burdens of legal retribution are reduced or even eliminated. It does so through attitudinal and behavioral changes that increases the prospects for reconciliation.

One informant from the government actors observed that:

Informal peace committees have faced the greatest test in trying to reintegrate both the victim and the offender citing the case of Internally Displaced Persons in Kenya (IDPs). The offender and the victim probably need to be reintegrated into the community after so much condemnation, prison sentencing, or even after the punishments from the judicial system or community, citing the case of people who were arrested and later released by the courts after the violence. The role of the community in the reintegration process was vital. Each individual, therefore, needs one another for the moral solidarity of society and one cannot exist apart from the community to which one belongs. In most instances, the offender's feet alienated and cut off from society as a result of crime. However, it was the responsibility of the rest of the community to work hard to integrate them into the society despite the harm they had caused. While informal peace committees played a critical in peace building role it was almost impossible to reconcile if the society did not embrace the idea.

It emerged that civil war is commonly viewed as the result of a fracturing of society resulting in social disintegration. Civil war is not purely the disintegration of society. Instead, it is more accurate to describe it as the disintegration of the broad social community, and the social integration of certain members of the community into a new social fabric: the war family. In other words, civil war is both a destructive and constructive process; disintegrating broader social bonds, while constructing smaller more exclusive ones. Social integration is not only a positive process with a peaceful outcome, but can also provide a foundation for the formation of competing group identities. The challenge after war is not only to reintegrate combatants into society, but also to address the social bonds of the war family and combatant society. This statement corroborated with (Jennifer M, 1994), who argued that during war social disintegration takes place on various fronts: social, economic, and political. Social disintegration, as discussed here, is the breaking of community bonds between individuals and the disassociation of the individual from community beliefs, norms, laws, structures, and goals. Social disintegration worsens with time and with higher levels of violence, especially when this violence targets civilians. Social disintegration involves the fragmentation of society, the exclusion of groups from power and access to economic goods, and the polarization of communities as individuals take sides in the war. The following briefly highlights some common patterns of social disintegration during civil war. First, there is the disintegration of community ties leading to fragmentation. There is the clear break between combatant and non-combatant groups, in terms of who belongs or is considered a member of each community. Social disintegration affects all members of a community during wartime. Community members are forced to choose which faction they support and whether they will fight or not

\section{An informant from the religious group noted that;}

The informal peace committees have not been able to achieve maximum support to advocate for a culture of dialogue and acknowledgement within the community on a day-to-day basis and to help to mobilize the community for dialogue sessions. Informal peace committees experience the challenge of advocating for a culture of dialogue and acknowledgement between the communities living in Nairobi County.

This highlighted the challenges associated with the lack of capacity to advocate for a culture of dialogue in conflicts. This contradicts with the work of (Community Social Peace model 2001), in Burundi which observed that in preparation for the community dialogue, the community identifies and delegates its representatives. It is advisable to let the communities themselves identify individuals they deem suitable for the process. The group meetings with the various communities could serve this purpose. Once the buy-in of the community has been secured, and the process explained to the members, they are encouraged to select their representatives to the dialogue sessions. It is important to ensure that during the group meetings, the voices of the various stakeholders, such as women, youth and other marginalized groups, are heard. In the process of selecting the focal points/champions, it is helpful to take into account moral credibility, commitment to dialogue and the ability of the proposed focal persons to clearly convey messages verbally and/or in writing.

Many groups will be uncertain about how the process will play out. In such situations, they may send extremists, hatemongers or those they believe will best defend their interests to these meetings. If this happens, it is advisable not to reject these people. Since they have the confidence of their community members, rejecting them gives the impression to the community that the process contains other motives than the ones stated. The challenge is to transform their attitudes and perceptions and convert them into peace champions. Once transformed, you cannot find more committed and devoted advocates for peace. However, despite the challenges, informal peace committees have wide opportunities as (Matavire. M. 2012) noted that traditional justice mechanisms have the potential to bring out the truth about past human rights violations as the perpetrators are allowed to present 
their stories and narrations in community based environments where their safety is guaranteed by the rest of the community. As much as in modern criminal prosecutions and court processes the risk of half - truths, lies and manipulation of information can never be done away with. However, the fact that a perpetrator comes seeking for community cleansing and is also aware of the need to "cleanse" his own family of social ills bedeviling his relatives facilitates a natural inclination towards bringing out the whole truth. The kind of social and community ostracism that accompanies perpetrators who are perceived to be uncooperative with the truth seeking process is enormous.

However all is not lost for the informal peace committees. (M Minnow, 1998), argued that as much as deterrence is seen to be the preserve of modern day judicial systems, informal peace committees have the potential and ability to deter future human rights violations perpetrated in communities. The avenging spirits against the perpetrator and his or her family is one mechanism that has played a huge role in ensuring that young people do not engage in criminal activities in the name of political parties or other motives. The spiritual sanction removes collective guilt that is usually abused to hide behind gross criminal acts and it individualizes the offence. This method of holding criminals accountable spiritually by the avenging spirits of the dead has helped to individually hold criminals responsible rather than communal.

\section{DISCUSSIONS AND RESULTS OF THE FINDINGS}

It emerged that the informal peace committees had continuously been involved in promoting dialogue, reconciliation and building peace and human communities in Nairobi County. However, it emerged that they had serious weaknesses in their structure and performance. Although informal peace committees looked inclusive in their structure, they didn't fully incorporate some local actors such as the local NGOs and civil society working for the promotion of human rights at the local level. Some of those NGOs and civil society groups in the study area had very good networks. It also emerged that informal peace committees didn't include other NGO leaders and civil society actors who had good networks and popularity among the local community. Had it included them, the informal peace committees would have definitively earned more support and increased trust from the people.

It emerged that lack of resources posed serious challenge to the functionality of the informal peace committees in Nairobi County. Due to the lack of financial and logistic resources, the informal peace committees could not act effectively in some emergency situations. This kind of situation sometimes strained the relations between them and the local authorities. This dynamic indicated a dearth of vertical and horizontal relationships among leaders. The lack of educated committee members was another big challenge faced by the informal peace committees. As a result, they could not reach their potential. Similarly, informal peace committees had not been concerned enough about research and other studies. Because of its lack of resources, they were not able to document all the issues related to conflict and peace building in the County. In addition, due to its limited relationships with other civil society organizations, they were not able to initiate partnerships to promote peace, human rights, or harmony in the local communities.

It emerged that informal peace committees lacked cooperation from other governmental organizations. This was attributed to their temporary structure. The bureaucratic sectors usually did not seriously cooperate with the informal peace committees as with other peace actors for example the cohesion and integration commission. This lack of official recognition by the state didn't auger well with their operations despite their enormous contribution to peace building in Nairobi County. The question of legitimacy and state recognition of informal peace committees was widely raised. There was considerable debate among the respondents on how they could be integrated into state structures and seek ways to maintain them without external financial or organizational assistance. This issue raised all kinds of questions about the design of such committees. First, which and whose notions of peace, justice and societal change should they promote? Who wins by their kind of conflict mitigation and resolution, and who falls out? How do they impact on women and gender relations? How to assure that the structures remain equally accessible to everybody?

Respondents were concerned on how supporting informal peace committee would complement other interventions. In other words, what was the added value of informal peace committees if peace builders aim to contribute to Peace-Writ-Large? Even if informal peace committees had limited impact beyond the confines of their communities, to what extent did they nonetheless address more general political and social problems, and contribute to societal transformation? Again, respondents raised the issue of relationships between newly established structures and existing local institutions. Respondents were concerned that customary regulation, particularly those that favored men over women, or one social group over another? In the same breath, the legal ambiguity, a proliferation of local institutions, and unclearness about who was in charge and what rules applied came in the fore. And if informal peace committees were phased out, which of their attributes should be retained in other institutions? A key dilemma was to what extent such forms of justice and security provision might be at the disadvantage of the re-establishment of the state, and might release the state of its responsibility to take care of its citizens.

Respondents felt that informal peace committees were unable or didn't have capacity to hold people responsible for violence accountable for their deeds. They emphasized how justice may be arrived at in various ways, including through truthfinding, acknowledgement of wrongdoings and apology, or (symbolic) compensation. In the prioritization for peace it was notably motivated by observed shortcoming in the state justice system than by dislike of punitive justice. Various respondents considered that informal peace committees should play an important role after formal justice has been dispensed: in reconciling the parties and reintegration of the punished. This suggested the added value of informal peace committees even after the justice sector had been re-invigorated. They held that, an important question to consider was what local people considered as just and to what extent are such considerations promoted by informal peace committees and state justice systems. The respondents felt that informal peace committees had not exploited opportunities available for them in peace building. They felt that the committees should be able to unravel contradictions in the 
sources of any conflict. They should seize the opportunity to represent the roots, the underlying causes of the incompatibilities in a conflictual relationship. These contradictions emerge along the different societal fault lines, and exist most of the time on a subconscious level. Generally, contradictions may arise when certain groups are excluded or marginalized from the political, economic and social participation, where there is a high level of unmet individual and collective needs, where poverty in endemic or where the abuse of power and corruption creates inequalities and injustice within the society. Again, the informal peace committees should be in the frontline to shape attitudes that represents subconscious pillars of the conflict, factors conflicting behavior, holding it in place. Attitudes are revealed in the perception of the conflict actors towards themselves, others, the conflict, the goals of the conflict and the strategies chosen to reach the goals. They should also address the behaviors as a conflict pillar which represents the visible, conscious element of the conflict, individual or collective manifestation of action/ inaction toward the attainment of a certain goal. Depending on the measures and tools used, the behavior may be destructive and constructive.

\section{REFERENCES}

[1] Amstutz Mark R., The Healing of Nations: The Promise and Limits of Political Forgiveness, Rowman \& Littlefield Publishers, September 2004, 296p.

[2] Bar-Tal, D. (2007). Living with the conflict: Socio-psychological analysis of the Israeli-Jewish society. Jerusalem: Carmel (in Hebrew).

[3] Gastrow, Peter, Bargaining for Peace - South Africa and the National Peace Accord, United States Institute of Peace, Washington DC, 1995

[4] Galtung, Johan (1996). Peace by Peaceful Means - Peace and Conflict, Development and Civilization. Oslo: PRIO.

[5] Goetz, A. M. and R. Jenkins (2005) 'Introduction', in Goetz and Jenkins, Reinventing Accountability: Making Democracy Work for Human Development, International Political Economy Series, Basingstoke, Palgrave Macmillan.

[6] Hegre, Håvard, Ellingsen, Tanja, Gates, Scott, Gleditsch, Nils Petter (2001) Toward a democratic civil peace? Democracy, political change, and civil war, 1816-1992. American Political Science Review 95(1): 33-48.

[7] Jacqueline M. Klopp and Elke Zuern. (2007). "The Politics of Violence in Democratization," Comparative Politics, vol. 39,no. 2 (2007), 127-146.

[8] Jenkins, Rob (2013), Peace building: From Concept to Commission. London: Routledge.

[9] Jeong, H.-w. (2000). Peace and conflict studies: an introduction Studies in peace and conflict research . Ashgate, UK : Ashgate Aldershot Publishers .
[10] Jenkins, Rob (2013), Peace building: From Concept to Commission. London: Routledge.

[11] Jeong, H.-w. (2000). Peace and conflict studies: an introduction Studies in peace and conflict research . Ashgate, UK : Ashgate Aldershot Publishers .

[12] Kamoet, A. (2007). A historical overview of Mt Elgon crisis. Proceedings of the Mt. Elgon Crisis workshop held at Masinde Muliro University of Science and Technology (21-26). Kakamega, Kenya

[13] Kothar, C. R. (2009 ). "Research Methodology: Methods \& Techniques" (Second Revised Edition), . New Delhi: New Age International Publishers

[14] May, L. (2010). Genocide: A Normative Account. . Cambridge : Cambridge University Press.

[15] Mathey, J. (2008). Come Holy Spirit Heal and Reconcile: Report of the World Council of Churches on World Mission and Evangelism. . Geneva: WCC Publications.

[16] Mbugua, J. (2013) "Inter-Communal Conflicts in Kenya: The Real Issues at Stake in the Tana Delta." International Peace Support Training Centre, 2013,

[17] Michael Barnett, 'Building a Republican Peace: Stabilizing States after War', International Security, 30, 4, 2006, pp. 87-112.

[18] Odendaal, A., 2008, 'Local peace building forums: Rationale and methodological hypotheses', UNDESA-DPADM and BCPR Ad Hoc Expert Group Meeting on Reconstructing Governance and Public Administration Capacities for Conflict Prevention and Development, Accra, 2-4 October,

[19] Sangqu, S., 2014, 'A crucial link: Local peace committees and national peace building', African Security Review 23(4), 422-424. https://doi.org/10.1080/10246029.2014.956472

[20] Simiyu, R. (2008). Militarization of Resource Conflicts: The Case of LandBased Conflict in the Mount Elgon Region of Western Kenya. Pretoria: Institute for Security Studies.

[21] van-Tongeren, P. (2013). Creating infrastructures for peace -experiences at three continents. PENSAMIENTO PROPIO, Vol.36, No.37, pp.91-128

[22] Walter, Barbara F. 2002. Committing to Peace: The Successful Settlement of Civil Wars. Princeton University Press.

[23] Wallensteen, P., \& Swain, A. (1997). Environment, Conflict and Cooperation. In D. Brune, D. Chapman, M. Gwynne, \& J. Pacyna (Eds.), The Global Environment. ence, Technology and Management (Vol. 2, pp. 691704).

\section{AUTHORS}

First Author - Gacaga Peter Mungai, Department of peace and conflict studies Masinde Muliro University of science and Technology

Second Author - Prof Crispinous Iteyo, Department of peace and conflict studies Masinde Muliro University of science and Technology

Third Author - Dr. Janet Kassilly, Department of peace and conflict studies Masinde Muliro University of science and Technology 